\title{
The Models of Sovereignty in the South Caucasus
}

\author{
Gayane Novikova*
}

\section{Introduction}

Over the last five to six years we have witnessed dramatic changes in the international security environment - changes that have directly influenced developments in the South Caucasus. Among the most significant changes are the world economic crisis, the Arab awakening, and the turbulence and civil wars all over North Africa and the Middle East.

There is also a growing number of secessionist movements, indeed even in the prosperous parts of Europe: Scotland and the Flemish region will hold referenda on independence from Great Britain and Belgium, respectively; separatist trends are under way in Catalonia and in the Basque country in Spain, as well as in Quebec in Canada. Great Britain is debating abandonment of its EU membership.

It is not by chance that we are also witnessing the appearance of several internationally recognized sovereign states, even though they are either essentially failed states or very weak. There is also a group of state entities that can be considered as conflict-ridden exceptions. Among them are the semi-recognized Abkhazia and South Ossetia, as well as the unrecognized Nagorno-Karabakh Republic.

In many ways these developments are related to the issue of state sovereignty. The pillars of this concept are sovereignty over a territory and a population, over decisionmaking in governance, as well as over the state's interaction with other states and international organizations. The notion of sovereignty offers a framework for the state's behavior and for its population generally. It influences directly its degree of security, stability, and prosperity.

In accordance with international law and the UN Charter, all states are equal. Despite this ideal, a given state's level of political, economic, and social development defines its degree of sovereignty and its role in international affairs. However, the sovereign state per se must meet two criteria: self-rule and self-protection. The second criterion is easier to implement, while the first is almost impossible to put into practice in a rapidly globalizing world. ${ }^{1}$ A further important measurement is a state's stage of democratization.

\footnotetext{
Dr. Gayane Novikova is the founding director of the Center for Strategic Analysis in Yerevan, Armenia (since 2001). She teaches courses on Russian foreign policy in the UNESCO Department on Human Rights, Democracy and European Studies at Yerevan State Linguistic University. She was a Fulbright Scholar (2008-2009) and a Visiting Scholar (2012-2013) at the Davis Center for Russian and Eurasian Studies and a Visiting Scholar in the Near Eastern Languages and Civilizations Department at Harvard University (2009-2013), as well as a Visiting Lecturer in the International Relations Department at Boston University (2011, 2013). Her areas of expertise cover international relations and regional security issues, including ethno-political conflicts and unconventional threats, Russia's politics in the South Caucasus, and the EU Eastern Neighborhood Policy.

1 For more details, see Omar Dahbour, Self-Determination without Nationalism: A Theory of Postnational Sovereignty (Philadelphia: Temple University Press, 2013), 190-93.
} 
With regard to the developed democracies, there are some important areas in which shared sovereignty is a factor. The two primary European organizations - the European Union and NATO - take responsibility for critical developments in Europe. The austerity measures imposed by the EU (under German leadership) upon the economies of Greece, Spain, and Portugal offer examples of limitations upon these states' sovereignty. However, the consequences of these limitations are significant: the Euro zone has been able to move toward a slow recovery from the 2008 economic crisis.

With respect to the failed states, the leading international organizations sometimes consider the imposition of full control over the economic and political resources of these states as a means to maintain security and prevent the spread of terrorist activity. The latter has become more and more critical, especially in those areas of overt religious conflict. (Recent examples include the international military operation in Northern Mali, and the recent attack in Nairobi, Kenya).

In the meantime, there have been several cases where, "in the name of democracy, international organizations adopted new mandates, such as 'responsibility to protect,' and regional charters of democratic standard-setting and conditionality." ${ }^{2}$ There are examples of the forcible introduction of democracy by European states and the U.S., coordinated with military operations against sovereign states (Iraq, Afghanistan, SerbiaKosovo, etc.). The suspension of the national sovereignty of internationally recognized UN member states, which took place in all these cases, was implemented without the consent of the governments involved.

Another trend related to the participation of sovereign states in international organizations should also be mentioned. In November 2013, several sovereign states had to decide whether they would or would not sign the different preliminary agreed-upon Association Agreements with the European Union at the Third Eastern Partnership Summit in Vilnius. According to the initiators, this broader involvement in the Eastern Partnership Program was aimed to improve their relations with the EU, to speed their democratization and good governance processes, and - to a certain extent - to diminish Russia's influence and pressure upon the former Soviet Republics (a matter that has taken on a strikingly different valence in the wake of Russia's response to the unrest in Ukraine).

The above-mentioned developments and processes directly relate to discussions of sovereignty. Even more, they contribute to the "mutation" and the "melting" of sovereignty per se. Furthermore, although sovereignty cannot be considered as absolute, it is still a key factor for any state and for nation-building processes, especially with regard to sovereignty over a territory and to relative decision-making freedom. The crucial questions to be answered are: How do sovereign states interact with each other in a rapidly changing and globalizing world? To what degree are the state entities prepared to delegate a part of their sovereignty to international organizations, or to share it with another state?

2 Lawrence Whitehead, "State Sovereignty and Democracy," in New Challenges to Democratization, ed. Peter Burnell and Richard Youngs (New York: Routledge, 2010), 24. 
State sovereignty in the vulnerable South Caucasus region is directly linked to the specific territory and to issue of security. The analysis offered in this article will focus on the following questions:

- What does sovereignty mean for each actor in the South Caucasus?

Does each actor in the region have enough maneuverability to implement and maintain its sovereignty?

- Under what circumstances, and to what extent, is the state entity prepared to share with (or delegate to) other actors a part of its sovereignty?

- Finally, what models of sovereignty are applicable for the state entities of the South Caucasus?

Before answering these questions, the following points should be emphasized. First, the South Caucasus state entities are neither developed democracies nor failed states. They are - to varying degrees-insecure economically, politically, and socially. The strongest among them is Azerbaijan; the weakest is the South Ossetian Republic. There is also a diversity of achievements in regard to democratization: from autocratic Azerbaijan and South Ossetia to partly free Armenia, Georgia, Abkhazia, and NagornoKarabakh. $^{3}$

Second, owing to the wide range of their internal problems and the interregional security trends, the South Caucasus state entities possess very limited maneuvering space. The choice mainly is between an Associative Agreement with the EU and membership in Russia's Customs Union, and subsequently in the Eurasian Union. Both options are, on the one hand, very vague. On the other hand, given the course of recent developments, they are becoming mutually exclusive. Armenia's failed attempt to synchronize its relations in both directions is a vivid example of the unwillingness of the EU and Russia to share areas of influence and strategic interest. ${ }^{4}$ As Peter Burnell has written,

For the EU, the distinctive challenge is to repeat its successful strategy of supporting democratic consolidation of post-Communist European states by making offers of conditional membership of the EU. As the process of EU enlargement comes to an end and the states in the neighborhood as well as others much farther away have no prospect of mem-

32013 Freedom in the World (Washington, D.C.: Freedom House Report, 2013); available at http://www.freedomhouse.org/report-types/freedom-world.

4 For Armenia it is critical that the relationships with both Russia and the EU be improved in order to avoid the further growth of authoritarianism and to provide adequate security to itself and the Nagorno-Karabakh. However, on 3 September 2013, on the occasion of his visit to Moscow, President S. Sargsyan stated that it was Armenia's intention to join the Customs Union. This statement was very unexpected by both European Union officials and the Armenian public at large. The EU reaction was quite predictable: "However, given Armenia's wish to join the Customs Union of Russia, Belarus and Kazakhstan, announced in September 2013, the Association Agreement, incompatible with membership in the Customs Union, will not be initialed nor signed. The European Union will continue cooperation with Armenia in all areas compatible with this choice." For more details, see the statements and discussions regarding the decision of the Armenian leadership at: http://eeas.europa.eu/armenia/index_en.htm. 
bership, and as many of them lack liberal democracy's most generally accepted conditions or credentials, the EU's ability to exert influence is much reduced. ${ }^{5}$

For Russia, inclusion of the former Soviet republics into the Eurasian Union implies a clear indication of its intention to secure (and to control) the area of its direct strategic interests, in line with its national security strategy. Thus, critical for all South Caucasus state entities is a capacity to balance between the EU and Russia. They do so, in both cases, at the cost of their state sovereignty.

\section{Sovereignty: From "By Any Means" To "By No Means"}

"Sovereignty" per se, for the newly independent states and state entities of the South Caucasus, is a magic word. It implies a desired step toward a restoration of their independence or a proclamation of it for the first time in many years. Hence, the notion of becoming a "nation-state" in the full sense of the term is an absolute priority, and the most important component in the self-identity of state entities in the South Caucasus. In the case of this region, the degree of sovereignty each state possesses - and the perception of it by all state entities and all external actors involved-mirrors their different status in the international arena: Armenia, Azerbaijan, and Georgia are internationally recognized states; Abkhazia and South Ossetia are semi-recognized states; and the Nagorno-Karabakh Republic is an unrecognized but de facto state.

However, in spite of de jure differences in their international status, all state entities of the South Caucasus experience different degrees of insecurity, in certain circumstances threatening the territorial integrity and state sovereignty of their direct neighbors, as well as the security of their population. ${ }^{6}$ It is important to stress once again that the sovereignty of newly independent Armenia, Azerbaijan, and Georgia was in 1991 internationally recognized within the borders of the former Soviet republics. Nonetheless, their formal independence and international recognition were almost immediately violated in the course of internal ethno-political conflicts. Hence, there emerged as a consequence of these conflicts the Nagorno-Karabakh Republic, the Republic of Abkhazia, and the Republic of South Ossetia, with each claiming sovereignty over their historic territories, which were included in the former Soviet Republics of Azerbaijan and Georgia, respectively. ${ }^{7}$ The further transformation of internal ethno-political conflicts into

5 Peter Burnell, "New Challenges to Democratization," in New Challenges to Democratization, ed. Peter Burnell and Richard Youngs (New York: Routledge, 2010), 17.

6 Azerbaijan openly threatens NKR and Armenia; Georgia considers Russia as a major threat; Abkhazia and South Ossetia view Georgia as a direct source of threat; Armenia does not threaten Azerbaijan, but is ready to provide full-scale defense and security to NKR. Currently, the only real possibility of resumption of military action is in the area of the Nagorno-Karabakh conflict. At the recent meeting of the Armenian and Azerbaijani Presidents in Vienna on 19 November 2013, they "agreed to advance negotiations on a peaceful settlement of the Nagorno-Karabakh conflict" and to meet again in the next few months.

7 The contradictory versions of national histories have played a significant role in the aggravation of ethno-political conflicts in the South Caucasus. 
international territorial conflicts resulted in de facto alterations of state borders and the suspension of the sovereignty of Azerbaijan over the territory of Nagorno-Karabakh (and the territories surrounding it) and of Georgia over Abkhazia and South Ossetia. Thus, in the South Caucasus we are dealing with three types of state entities and with a diversity of sovereignty models. We are also dealing with a spectrum of approaches to the challenge of how best to preserve sovereignty - from "by any means" to "by no means."

In this analysis the terms "sovereignty," "shared sovereignty," and "residual sovereignty" will be used. The latter must be understood as the lowest level of state sovereignty. Another important issue related to the models of sovereignty at work in the South Caucasus is the complex and overlapping correlation between self-determination and sovereignty. ${ }^{8}$ The sovereignty of the internationally recognized states directly influences the right of self-determination; conversely, the claim for self-determination of the given state entity reduces the sovereignty of the "metropolitan" state over its territory and population.

\section{Georgia-Abkhazia-South Ossetia}

For internationally recognized Georgia and Azerbaijan, the restoration of their territorial integrity is a strategic goal with a strong symbolic meaning. The unsuccessful attempt of the Georgian leadership in August 2008 to resolve this issue by military means changed the status quo in the "Georgian conflicts." The recognition by Russia and several sovereign states of the independence of Abkhazia and South Ossetia de jure confirmed and supported the latter's sovereignty over the territories they claimed as their own. But it also put them into a situation of complete dependence upon Russia as their patron. This development therefore de facto sharply reduced their sovereignty over their territories and their populations, as well as over their independent decision-making capacity. Any development in Abkhazia and South Ossetia depends to varying degrees upon Russia's interests.

The critical difference between Abkhazia and South Ossetia is that the latter cannot preserve its sovereignty by any means. It retains very limited options, and oscillates between being on the verge of a failed state and simply a Russian military base. To avoid these extremes, it must either share its sovereignty with Georgia (on the basis of a federal state) or delegate it completely to Russia, on the basis of unification with North Ossetia. If South Ossetia would consider shared sovereignty, then Georgia's move toward the EU (through an Association Agreement to be signed at the Eastern Partnership Summit in Vilnius) would be very helpful indeed for a future Georgia-South Ossetia reconciliation. However, the South Ossetian population, as it exists now, and a dominant part of its leadership prefer to shelter under Russia's umbrella. ${ }^{9}$

8 For more details, see Dahbour, Self-Determination without Nationalism, 191.

9 See, in particular, the statement of Leonid Tibilov, the President of the South Ossetia, on 24 July 2013: "For every Ossetian, the issue of unification of the people is a priority." He also stated that he "would consider his presidential mission fulfilled if South Ossetia by the desire 
With respect to Georgia-Abkhazia relations, the situation is more complicated. The consideration of a model of shared sovereignty with Georgia is already a thing of the past. ${ }^{10}$ However, the complexity of the status quo itself provides maneuvering space for Abkhazia, which has enough resources and capacity to maintain its status as a semi-recognized state (in this regard, the best example is Northern Cyprus, as recognized by Turkey). The relationship with Russia provides benefits for Abkhazia's economy and for its defense, but it also sharply reduces Abkhazia's policy- and decision-making options. ${ }^{11}$ Meanwhile, Abkhazia can benefit from Russia-Georgia antagonisms and gradually enlarge its sovereignty from residual to shared status through cooperation with Russia, Georgia, Turkey, and Armenia (the opening of a railroad through the Abkhazian territory constitutes an example of how this might occur).

The other side of this coin must be noted. The very existence of Abkhazia in its current semi-recognized status is a de facto and de jure reduction of Georgia's sovereignty over its internationally recognized territory. The ability of Georgia to accept this reality and to search for ways toward cooperation will contribute to mutual understanding and trust between all entities concerned. Owing to the perception that Russia poses a direct security threat to Georgia's sovereignty, ${ }^{12}$ Georgia is rapidly moving in the European direction. Any level of participation in European institutions and organizations is considered as a guarantee along the pathway toward preservation of the sovereignty of this South Caucasus state over its territory and population. There is also a strong under-

of its citizens were to unite with Russia and the reunification of the Ossetias would occur." "Tibilov: My mission will be accomplished if South Ossetia unites with Russia," Information Agency Regnum; available at http://www.regnum.ru/news/polit/1687422.html. "Should there be a united Ossetia?" The Caucasus Echo; available at www.ekhokavkaza.com/content/article/ 25056026.html.

10 The last model for the resolution of the Abkhazian conflict was introduced in a speech by President Saakashvili in March 2008, who offered to Abkhazia "free economic zone, post of Vice-President of Georgia, unspecified security guarantees, 'unlimited autonomy'." For details, see "Saakashvili Outlines Tbilisi's Abkhaz Initiatives," Civil Georgia (28 March 2008); available at www.civil.ge/eng/article.php?id=17473.

11 The Abkhazia-Russia relationship is developing in several areas. However, there is a growing understanding in the Abkhazian political establishment regarding the growing dependence of Abkhazia on Russia. Internal disagreements among the Abkhazian elite will push the leadership to search for ways to minimize dependence on Russia by increasing cooperation with neighboring countries. See Sergey Markedonov, "Abkhazia: Russia's Attempts to Create a Nation-state," Russia \& India Report (16 October 2013); available at http://indrus.in/opinion/ 2013/10/16/abkhazia_russias_attempts_to_create_a_nation-state_30183.html. See also "Russian Ambassador Assassinated in Abkhazia," The Washington Post (11 September 2013); available at www.washingtontimes.com/news/2013/sep/11/russian-ambassador-assassinatedabkhazia/.

12 According to the National Security Concept of Georgia, "The 2008 war demonstrated that the Russian Federation does not accept the sovereignty of Georgia, including Georgia's choice of democracy and its independent domestic and foreign policy." Available at www.nsc.gov.ge/ files/files/National\%20Security\%20Concept.pdf. 
standing in the Georgian political and business establishment, as well as in the society at large, that the country will benefit from further democratization.

Furthermore, conflicting approaches to security and sovereignty in Abkhazia and Georgia reduce the possibility of reconciliation between these two state entities - even in the medium term. To differing degrees, Georgia and Abkhazia are sharing their sovereignty with the European Union and Russia, respectively, which compete in many spheres. The shared sovereignty model between Georgia and Abkhazia can be considered only within a "soft power" framework, namely, in the human and, perhaps, ecological areas. ${ }^{13}$

Summing up the developments in this Georgia-Abkhazia-South Ossetia triangle, it must be stressed that while South Ossetia is ready to delegate sovereignty completely to Russia, Abkhazia is trying to preserve it by applying for Russian support, even through acknowledging the high price that is being paid. Georgia views itself as more advanced - namely, as a "European state" in the South Caucasus. It hopes that the advantages of inclusion into the European security and economic systems will sooner or later assist in the discovery of frameworks for reconciliation with Abkhazia and perhaps for reintegration with South Ossetia.

\section{Armenia-Nagorno-Karabakh-Azerbaijan}

The developments in the triangle Armenia-Nagorno-Karabakh (NKR)-Azerbaijan are different and more complicated, owing to the fact that the implementation of the right of the Karabakhi Armenians to self-determination has not only violated the territorial integrity and sovereignty of internationally recognized Azerbaijan, but also transformed the developments into a protracted inter-state conflict. ${ }^{14}$ Azerbaijan is the only state in the South Caucasus capable of maintaining sovereignty over its economy and defense. It has no need to share sovereignty with, or to delegate a part of it to, any international organization. However, there is a dualism at work in Azerbaijani perceptions of its sovereignty: on the one hand this state claims a role as a regional power, and on the other hand it has lost its sovereignty over a section of its internationally recognized territory. Thus, a restoration of its territorial integrity is a strongly articulated priority and a precondition for the fulfillment of its desire to play a role as a regional power. Moreover, it should be stressed that, in comparison to Georgia, Azerbaijan does not rely directly on any international organization or state to assist in the restoration of its territorial integrity, but it demands from international organizations the legitimization of the possibility of the resolution of the conflict by force. Furthermore, as implied, neither Russia nor the

13 In the meantime, the new Georgian leadership is moving cautiously toward a reconciliation with Russia. The positive developments in Russia-Georgia relations to some extent will positively influence the Georgia-Abkhazia relationship.

14 It should be mentioned that there was initially a conflict of sovereignties of Azerbaijan and Nagorno-Karabakh in the pre-Soviet, Soviet, and post-Soviet periods. In 1991, recognizing Azerbaijan as existing in the borders of the Azerbaijani SSR, the international community indirectly contributed to the further escalation of the Nagorno-Karabakh conflict. 
EU possesses any real leverage (or at least, are not interested) to influence Azerbaijan's domestic or foreign policy. Armenia is another internationally recognized state in this triangle. Although it possesses limited economic resources (in comparison to Azerbaijan) to support maintenance of its sovereignty, it has enough military power to preserve its territorial integrity and to provide the necessary military support to the NKR. In the meantime, its direct involvement in the Nagorno-Karabakh conflict sharply reduces its maneuverability and renders it very sensitive to any changes around the NKR. On the one hand, the security of the two Armenian state entities is an absolute priority for any Armenian president and any Armenian government. On the other hand, the prioritized security issue directly and indirectly limits Armenia's sovereignty in decision making, and strongly influences its relationship with its direct neighbors, as well as its domestic policy. A vivid example must be mentioned: the decision of the President of Armenia, Serzh Sargsyan, to apply for membership in the Customs Union despite the existence of already discussed, agreed upon, and prepared documents intended to be signed at the Third Eastern Partnership Summit in Vilnius was motivated (according to the official statements) by broad security reasons.

Hence, in this matter Armenia has once again confirmed that Russia is a strong component of its defense and security policy. Armenia completely shares its sovereignty with Russia in these two areas. Other areas where the shared sovereignty model is applicable concern the Armenian economy, in particular its growing dependence upon Russian investments, ${ }^{15}$ and demographic developments owing to changes in Russian migration policy and to emigration trends from Armenia in general. ${ }^{16}$

Parts of the Armenian political establishment speculate that the sharp U-turn toward the Eurasian Union was related directly, on the one hand, to the security threat posed to NKR and Armenia by Azerbaijan. On the other hand, there is a cognizance that limited possibilities still exist for further improvement in Armenia-EU relations. ${ }^{17}$ Another group of Armenian analysts and politicians argues that Armenia is losing its sovereignty. ${ }^{18}$

15 Although the EU is the first economic partner of Armenia, the level of EU investments has been significantly lower than Russia's. In light of the recent decision by the Armenian authorities, they will continue to decline. "Russian Direct Investments Make up 39.5\% of Foreign Direct Investments into Armenia's Economy," ARKA News Agency (5 September 2013); available at http://arka.am/en/news/economy/russian_direct_investments_make_up_39_5_of_ foreign_direct_investments_into_armenia_s_economy/.

16 According to the National Statistics Bureau of Armenia, on 1 April 2013, the population of Armenia was 3.029 million, against 3.275 million on 1 April 2012. In January-March 2013, 259,200 Armenian citizens left the country. In the same period, 223,700 people arrived in Armenia. The negative balance is 35,500, in comparison to 25,400 in the first quarter of 2012 .

17 Please see the statements of EU officials regarding the Armenia-EU relationship at http://www.aysor.am/en/news/2013/11/22/traian-hristea/ and http://www.rferl.org/content/ armenia-european-union-/25105725.html.

18 On 25 October 2013, in Minsk, Armenia signed a memorandum on intensification of cooperation between Republic of Armenia and the Eurasian Economic Commission according to which it is obliged to refrain from offering any statements or actions contradicting the inter- 
The third constituent part of this triangle is the Nagorno-Karabakh Republic. Its residual sovereignty is gradually expanding toward shared sovereignty with Armenia owing to internal positive developments in this de facto state and a strong interdependence between Armenia and the NKR, especially in terms of security. However, this interdependence significantly reduces the space available to both Armenia and the NKR for maneuvering, particularly in the areas of economic and foreign policy. It must be stressed that the lack of information in regard to crucial decisions on Armenian security, including the management of the Nagorno-Karabakh conflict, on the one hand, contributes to a growing apathy and - to a certain degree - mistrust throughout the Armenian society at large. On the other hand, there are several correlated questions: How does the sovereignty that Armenia shares with Russia influence the Nagorno-Karabakh Republic's claim for self-determination and independence owing to the latter's strong (if not complete) dependence upon Armenia? How does the NKR's residual sovereignty contribute to-or, conversely, damage-Armenia's sovereignty and even force Armenia to delegate significant parts of its sovereignty to Russia? To what extent does Russia wish to play a role as a security shield to Armenia (and would the NKR be included?) in the context of growing mutual strategic interests between Russia and Azerbaijan?

It is difficult to formulate clear answers to any of these questions. Also, there is no sign of any possible cooperation, even in the area of soft power initiatives, between Armenia, the NKR, and Azerbaijan. Seeking to play a role as the regional power, Azerbaijan is not prepared to discuss the issue of sharing its sovereignty with the NagornoKarabakh Republic. In its turn, Nagorno-Karabakh considers its de facto state status as an absolute and nonnegotiable priority. Although the NKR cannot exist without significant and diversified support from Armenia, the possibility of the unification of the two Armenian state entities is not discussed between them either. ${ }^{19}$ And Armenia (partly because of this complex situation) cannot allow itself to act without taking into serious consideration any implications for the NKR's security and defense.

ests of the members of the Customs Union. This memorandum has a direct negative influence on the Armenian position in the Nagorno-Karabakh conflict. The Prime Minister of Armenia in responding to a question posed by one of the Armenian MPs regarding this memorandum and the statement of the President of Kazakhstan regarding the resolution of the NagornoKarabakh conflict, mentioned in particular the following: "Indeed, many of our partners in the Customs Union and CSTO, unfortunately, often do not respect earlier reached political agreements, and make decisions that do not meet the interests of Armenia." See, in particular, The Euroasian Economic Commission and Armenia Signed a Memorandum for Deeper Cooperation; available at: http://ria.ru/world/20131106/975071901.html. "Tigran Sargsyan expressed dissatisfaction with the position of individual members of the Collective Security Treaty Organization and the CU regarding the Karabakh conflict," ArmInfo Information Agency (13 November 2013); available at www.arminfo.info/index.cfm?objectid=A4F1F1404C79-11E3-91930EB7 C0D21663.

19 An interesting analysis of Armenian geopolitical culture as concerns the internal tensions over how to present Nagorno-Karabakh, and its surrounding territories, is provided by Lawrence Broers and Gerard Toal in "Cartographic Exhibitionism? Visualizing the Territory of Armenia and Karabakh," Problems of Post-Communism (May-June 2013): 16-35. 
Thus, in the Armenia-Nagorno-Karabakh-Azerbaijan triangle, we are dealing with three models of sovereignty in an absolutely turbulent external environment. These overlapping models of sovereignty (and visions of security) produce a high level of ambivalence and contribute to growing tensions between all three actors.

\section{Conclusion}

As mentioned above, in the South Caucasus there are three types of states, and three strongly interconnected models of sovereignty. This diversity (see Table 1 below) in regard to sensitive security issues complicates internal developments in each state entity of this area and their interactions (or lack thereof) with each other.

Azerbaijan is ready to restore its territorial integrity by force - or "by any means"(at least according to the official state position) and is making plans to enjoy its restored sovereignty. There is no sign of any willingness to consider the option of shared sovereignty with the NKR, or with Armenia over Nagorno-Karabakh. In turn, the NKR is preparing to preserve its sovereignty over the territory of Nagorno-Karabakh and the

Table 1: State Entities and Sovereignty in the South Caucasus.

\begin{tabular}{|c|c|c|c|c|}
\hline State entity & Status & $\begin{array}{l}\text { Level of } \\
\text { sovereignty }\end{array}$ & $\begin{array}{l}\text { External } \\
\text { dependence }\end{array}$ & $\begin{array}{l}\text { Violation of } \\
\text { sovereignty }\end{array}$ \\
\hline Armenia & $\begin{array}{l}\text { Internationally } \\
\text { recognized }\end{array}$ & Shared & Russia & $\begin{array}{l}\text { Over decision } \\
\text { making }\end{array}$ \\
\hline Azerbaijan & $\begin{array}{l}\text { Internationally } \\
\text { recognized }\end{array}$ & $\begin{array}{l}\text { Self-sufficient } \\
\text { (but over a } \\
\text { limited } \\
\text { territory) }\end{array}$ & None & $\begin{array}{l}\text { Over territory by } \\
\text { Armenia and } \\
\text { NKR }\end{array}$ \\
\hline NKR & $\begin{array}{l}\text { Internationally } \\
\text { not recognized }\end{array}$ & $\begin{array}{l}\text { Residual / } \\
\text { Shared }\end{array}$ & Armenia & $\begin{array}{l}\text { Over decision } \\
\text { making (by } \\
\text { Armenia) }\end{array}$ \\
\hline Georgia & $\begin{array}{l}\text { Internationally } \\
\text { recognized }\end{array}$ & Shared & EU & $\begin{array}{l}\text { Over territory (by } \\
\text { Abkhazia and } \\
\text { South Ossetia } \\
\text { directly), and by } \\
\text { Russia indirectly }\end{array}$ \\
\hline Abkhazia & $\begin{array}{l}\text { Internationally } \\
\text { semi-recognized }\end{array}$ & $\begin{array}{l}\text { Residual / } \\
\text { shared }\end{array}$ & Russia & $\begin{array}{l}\text { Over decision } \\
\text { making (by } \\
\text { Russia) }\end{array}$ \\
\hline South Ossetia & $\begin{array}{l}\text { Internationally } \\
\text { semi-recognized }\end{array}$ & Delegated & Russia & $\begin{array}{l}\text { De facto no } \\
\text { sovereignty }\end{array}$ \\
\hline
\end{tabular}


surrounding territories ${ }^{20}$ not only from Azerbaijan, but also from Armenia, rejecting the option of unification with Armenia. ${ }^{21}$ Partially, Armenia, owing to its support for the NKR position, is (to some degree forcibly) broadly sharing its sovereignty with Russia, and considers this nation a guarantor of Armenia's sovereignty and security. Thus, there are, on the issue of sovereignty, direct interdependencies between Azerbaijan, the Nagorno-Karabakh Republic, and Armenia. In this triangle there are several important issues that must be considered:

- The "melting" sovereignty of Armenia, which is more and more shared with Russia

- The strong, albeit partial (with the exclusion of the territory of Nagorno-Karabakh and the seven districts around it), sovereignty of Azerbaijan

- The residual sovereignty of the NKR (the main part of its sovereignty is shared with Armenia; the sovereignty over international relations/negotiations is delegated to Armenia).

The prospects of any shared sovereignty between Armenia and Azerbaijan over Nagorno-Karabakh remain impossible owing to the different political, economic, demographic, and military characteristics of these two internationally recognized states and their absolutely different visions and evaluations of the situation in the area of the international conflict around Nagorno-Karabakh. It is of critical significance that the NKR (supported by Armenia) completely rejects any option that involves discussing its sovereignty with the Azerbaijani side; on the other hand, it does not wish to delegate its sovereignty to Armenia. There are some groundless speculations - at least for now-regarding the recognition of the NKR by Russia and possible developments in the conflict area after Armenia's membership in the Customs Union. Both options completely depend upon Russia's vision of its role in the South Caucasus and upon whether the Customs Union and the future Eurasian Union will become "success stories" for Putin's Russia. Thus, under the current circumstances, the multi-level conflict between these state entities will become aggravated. Cooperation and discussion on shared sovereignty questions either between Armenia and Azerbaijan over Nagorno-Karabakh or between Azerbaijan and Nagorno-Karabakh are excluded.

With regard to developments in Georgia, and its relationship with Russia, Abkhazia, and South Ossetia, several issues should be noted. First, Georgia will be presented with

20 Azerbaijan claims these territories as its own; the NKR, backed by Armenia, considers it as a bargaining point in negotiations over the NKR's final status. According to the Article 142 of the Constitution of NKR, "Until the restoration of the state territorial integrity of the Nagorno-Karabakh Republic and the adjustment of its borders, the public authority is exercised on the territory under factual jurisdiction of the Republic of Nagorno-Karabakh." See The Constitution of the Nagorno-Karabakh Republic, available at http://www.nkr.am/en/ constitution/9/.

21 At the initial stage of the conflict in the beginning of 1988, the Karabakh Armenians demanded unification with the Armenian SSR. 
many opportunities if it signs the Association Agreement, including a Deep and Comprehensive Free Trade Agreement (DCFTA) with the EU.

Second, the newly elected president, as well as the newly appointed prime minister and his team, will try to avoid any tension in their relationship with Russia, although it is clear that Russia no longer poses a direct security threat to Georgia and that a scenario similar to 2008 will never again appear. Indeed, improvement of the Russia-Georgia relationship has occurred to a certain degree. However, there is a deadlocked situation regarding the discussions of Georgian versus Abkhaz sovereignty over the same territory: Russia considers itself as a guardian of Abkhazia's sovereignty, and hence opposes Georgia's intention to restore its sovereignty over Abkhazia. As concerns South Ossetia, it must be noted that the situation is aggravated owing to the clear intention of Russia to actually separate South Ossetia from Georgia and annex it. ${ }^{22}$

Of course, the movement toward Europe is a strong priority for Georgia, and its political establishment appears ready to share sovereignty with the EU and to delegate to it some degree of control over its defense and security issues. However, it is obvious that the EU in its current form is unable to help restore Georgia's sovereignty over Abkhazia and South Ossetia. There is a very vague probability that the European prospects of this South Caucasus state will open more space for cooperation between Georgia and Abkhazia, and therefore will bring these two state entities closer to each other, indeed even to the extent than an overshadowing of an issue of extreme sensitivity to both sides - sovereignty - will take place.

The more mutually acceptable model could involve shared sovereignty of Georgia and Abkhazia over the territory, resources, and population within the borders of an internationally recognized Republic of Georgia. The name of the state, one could speculate, could be changed to the Republic of Georgia and Abkhazia. This state could exist as a confederation of two juridically equal state entities. However, under current circumstances this model cannot be implemented.

In conclusion, sovereignty per se is critical for all South Caucasus state entities. It must be considered as one of the key factors that assist our understanding of the ways in which security and stability in the South Caucasus are managed. The willingness of the state entities to share it or to delegate it to other regional or non-regional actor(s) directly depends upon their security situation and the scale of threats posed by their neighbor(s). Under these circumstances, the broad regional cooperation will remain on a low level and will fail to expand beyond bilateral cooperation agreements with different regional powers. In other words, reluctant neighbor(s) will be mutually excluded.

22 Paata Zakareishvili: Why Russia Builds a 'Berlin Wall' around South Ossetia; available at http://slon.ru/russia/rossiya_stroit_berlinskuyu_stenu_vokrug_yuzhnoy_osetii-975777.xhtml. 


\section{Bibliography}

2013 Freedom in the World. Washington, D.C.: Freedom House Report, 2013.

Abkhazia: Russia's Attempts to Create a Nation-state. Russia \& India Report, 2013.

Broers, Lawrence, and Gerard Toal. "Cartographic Exhibitionism? Visualizing the Territory of Armenia and Karabakh." Problems of Post-Communism (2013): 16-35.

Burnell, Peter. "New Challenges to Democratization." In New Challenges to Democratization, 17. New York: Routledge, 2010.

Dahbour, Omar. Self-Determination without Nationalism: A Theory of Postnational Sovereignty. Philadelphia, PA: Temple University Press, 2013.

Russian Ambassador Assassinated in Abkhazia. The Washington Post (2013).

Russian Direct Investments Make up 39.5\% of Foreign Direct Investments into Armenia's Economy. ARKA News Agency, 2013.

Saakashvili Outlines Tbilisi's Abkhaz Initiatives. Civil Georgia, 2008.

Should there be a united Ossetia? The Caucasus Echo (2014).

Tibilov, Leonid. For every Ossetian, the issue of unification of the people is a priority. the President of the South Ossetia, 2013.

Tibilov: My mission will be accomplished if South Ossetia unites with Russia. Information Agency Regnum, 2014.

Tigran Sargsyan expressed dissatisfaction with the position of individual members of the Collective Security Treaty Organization and the $C U$ regarding the Karabakh conflict. ArmInfo Information Agency, 2013.

Whitehead, Lawrence. "State Sovereignty and Democracy." In New Challenges to Democratization, 24. New York: Routledge, 2010.

Zakareishvili, Paata. Why Russia Builds a 'Berlin Wall' around South Ossetia., 2013. 